\title{
The Serendipitious City in South East Asia-Urban Archetypal Design Principles from the Morphological 'Vernacular'
}

\author{
Puteri Shireen Jahnkassim ${ }^{1 *}$, Kamariah Kamaruddin ${ }^{1}$, Nurul Syala Abdul Latip ${ }^{2}$, Norwina Mohd Nawawi ${ }^{1}$ \\ ${ }^{1}$ Kulliuyah of Architecture and Environmental Design, International Islamic University Malaysia. E-mail: puter- \\ ishr@iium.edu.my \\ ${ }^{2}$ Dept of Architecture, Islamic Urban Heritage (MICBAH) Research Cluster, Fakulti Kejuteraan dan Alam Bina, Uni- \\ versiti Sains Islam Malaysia, Nilai, Negeri Sembilan, Malaysia
}

\begin{abstract}
Serendipitious' has been defined as occurring or discovered by chance in a happy or beneficial way. "A serendipitous encounter" thus generally means one or a series of unexpected but pleasant encounters. A city, which is serendipitious, is a physical form, which has configuration and features which allows such encounters to happen. This paper highlights vernacular-based principles which are needed to counter the modernisation and urbanisation trends in South East Asia, throughout studying the typological and morphological character of 'littoral maritime' cities which grew in the 15th century onwards across littoral or coastal straits of maritime Asia represent pre-modern vernacular-rooted forms from which contain patterns that are urban, yet naturally-balanced with the environment. As these grew as a result of maritime trade, it is highly densed yet still reflect ecological features and conditions are still intact. The paper reconstructs some of these patterns and identify four central character as a result of their urban which resonate with 'ecological themes': 1) accretion qualities; 2) river-gravitation; 3) fractality and 4) centricity. The paper argues that although these patterns emerge from medieval times, these maritime cities constitute a 'gentle' and ecologically-sound approach to development which can unite the co-existence of urbanisation and nature. In such conditions, the tropical jungle exists side by side with densed urbanisation. The paper uses the reconstruction of the former (pre-colonial) morphologies in South East Asia to demonstrate the character of these centers, which are organic and informal evolvements having certain morphologies, configurations, architectural structures and their similarities and common principles in terms of urban patterns and principles are discussed. The pursuit of the optimal balance between 'man' and 'nature' must reflect in a city which consider living beings as both animal, vegetation and man, and which are, at present, in danger of critical depletion, and eventually extinction. Cases of built language, topography, ecology, landscape forms and urban configuration patterns and parameters across the region are presented and the paper argues that the rise of sustainability in city planning favors the compact and densed formal patterns which are reflective of these centers across the coastline of the straits historically and these constitutes principles that can sustain ecology, climatic balance yet an active cultural conduit of the place.
\end{abstract}

Keywords: Green Cities; Tropical Urbanism; Tropical Eco-City; South East Asian Region; Tropicality; Eco-Architecture

Copyright () 2020 Puteri Shireen Jahnkassim et al.

doi: $10.18282 /$ adr.v2i2.890

This is an open-access article distributed under the terms of the Creative Commons Attribution Non-Commercial License

(http://creativecommons.org/licenses/by-nc/4.0/), which permits unrestricted non-commercial use, distribution, and reproduction in any medium, provided the original work is properly cited. 


\section{Introduction}

As cities in Asia develop rapidly, a gap that is consistently missing from theory and practice of urban design and development is the field and framework of urban design. In retrospect, urban design fields arose in the past, as architectural concepts had their focus on standalone buildings themselves, rather than the relationship with the public realm. However, as Elrahman and Asad (2020) argues in the context of developing countries: "Although urban designers are more concerned with the daily needs of users, and solving tangible problems, they are still not perceived as the decision makers in the eyes of citizens. Urban planners are the ones perceived with the power to make decisions about the city, since their profession operates on the higher levels of policy formulation.” They therefore suggest part of the solution as this: "In order for the urban design practice to be informed with the urban planning practice, it should also be theoretically related to the urban planning theory. Yet in all the above analysis and in theory, there is no clear connection mentioned or drawn from a theoretical base related to urban planning." This paper argues that there must be a link, an understanding, and identification of original patterns of planning in South East Asian cities, that led to the creation of comfortable and tropical pleasant urban cities of the past. Understand these are crucial to the strengthening, preserving, regeneration and enhancing the identity and character of these urban cities in the future. Although past patterns may result from 'unplanned' morphologies which grew organically from the pre-colonial trade-based dynamics of urban South East Asia, an understanding of these original morphologies is a necessity to instigate urban design authenticity and place-making goals in tropical South East Asia. Without unearthing and identifying these 'vernacular' morphologies and themes in urban planning, the urban design theory and practice would not be able to enhance the ultimate public spaces including related infrastructure, as well as transportation, landscapes, and community accommodations. Urban design, by definition, is the "design of city features" and focused on design and user experience and operates at the features and systems level. Urban design describes the physical features that define the character or image of a street, neighbourhood, community, township or the City. Yet eventual character of a town or center is ready a whole; the accumulation of various elements-at different scales - that impinge upon the visual and sensory perceptions of urban dwellers, and consequently, affect the relationship between people and the built and natural environment. The built environment integrates with the natural environment which includes features such seaviews, coastlines, shorelines, roof profiles, facades and shape-all of which are eventually incorporated into the urban design comprehensive strategy and framework. Citywide urban design recommendations can only be realised if certain urban planning of the past is understood to ensure certain 'serendipitious' qualities of the Asian city. Any city or township in Asia, must rebrand its own identity, through geographical, climate, cultural and "historical layering of planning" which will distinguish this particular brand of city from any other. Such planning result in 'urban' or 'quasi-urban' design elements which had gradually evolved from its traditional past can be reinstated and identification of its original beginnings to hybrid expressions which then evolved side by side with its colonialised history.

Moshe Safdie (1997) had said: In order to go forward and consider the city that might be, we must look at the many visions of our cities since the beginning of massive urbanisation that marks this century. The emergence of the debates of the emergence of the age of the anthropocene have earmarked the present decade and century with an urgency to develop ideas, themes and guidelines which differ from the past industrialisation age. While ecological science constitute a basis for theoretical frameworks to meet the need for guidelines for new developments to limit the destructive impacts of development, vernacular-based approaches based on studies of past formations and morphologies also contain lessons that point the way forward. Vernacular formations of the past are even more difficult to recall and model due to sedimentations by the ruptures caused by Colonialism; which caused a drastic effect on local regions. Yet these 'forms and urban elements constitutes a source of language and principle to create character in rising Asian cities. The paper maps such vernacular sites, urban siting and landscape elements in order to create a range of urban elements with variations that contain underlying sustainable principles. Urban morphology is used as a tool to unearth broad themes and principles, 
and these can be defined as 'Urban morphology refers to the study of urban form that focuses on the formation and transformation of urban forms of cities, towns, and villages over time; their spatial patterns at different scales; and physical characteristics to inform appropriate urban interventions to promote sustainable urban development‘. In South East Asian, an example is the $\mathrm{PhD}$ thesis of Widya Fransiska (2013) had looked at the morphology of Palembang in order to highlight strategies of city rebranding, identity-making and conservation. Musikawi et al. (2018) also has highlighted the key peculiar grid patterns and urban open spaces which has strong socio-cultural potential in the region.

South East Asian cities have developed so rapidly that much of its original patterns and forms have been erased and decimated. The need for a rooted urban design framework is urgent as centuries of colonisation have crucially and irretrievably decimated the local pattern and configurations causing cultural sedimentation. The recent satellite cities and new eco-cities of Malaysia, Singapore, and Indonesia have been developed based on imported theories such as the Garden city. An example is Putrajaya, Malaysia, which is now known for its urban heat island (Ibrahim and Jahn Kassim, 2018); the consequences which have been linked to imported theories of urban design, rather than locally-rooted evolvements. In a new decade, it is increasingly realised that principles of sustainable urbanism must be geographically and locally rooted devised, although its broad ethos can be derived globally. These has been defined as a range of architectural and urban design elements that reflect a certain consciousness of, and consideration of the cultural and geographical identity of a region or a population. The term 'urbanism' is defined as 'a way of life characteristic of towns and cities' and defined as 'a condition of permanence' and has been linked to the role of the vernacular, in which the term 'vernacular' also include past city-like formations and structures, its functions, typologies and urban space configurations. The focus on the vernacular must be past urban forms which can become an instigator of new climatic and environmental best practice. Formally, these include by creating the hierarchies of spatial progression while at the same time, creating cities, urban spaces including public and transitional areas of climatic attunement.

Alexander (1979), Knapp (1989), and Oliver (1997) showed how vernacular settlements are culturally meaningful and the sustainability of the vernacular from ideas and practices, and the alignment between past urban form and present ecological urbanism and design standards and climatic credentials (Jahn Kassim, et al. 2018; Foruzanmehr, 2015). Hence a crucial step is the outlining of attendant theoretical and design framework-rooted in localised forms and vocabulary-and based on patterns of the past. Based on this urgent need to reconstruct the urbanism and urban design of the past, past reconstructions are done at both architectural and city scale to identify broad patterns.

\section{Methodology}

\subsection{Cities in the littoral region}

The littoral zone or nearshore is the part of a sea, lake, or river that is close to the shore. In coastal environments, the littoral zone extends from the high water mark, which is rarely inundated, to shoreline areas that are permanently submerged. The littoral zone always includes this intertidal zone, and the terms are often used interchangeably. What is regarded as the full extent of the littoral zone, and the way the littoral zone is divided into subregions, varies in different contexts. (Lakes and rivers have their own definitions.)

The adjacency of water gives a number of distinctive characteristics to architecture and urban design in the littoral regions. These have ecological and sustainable lessons as their elevated and compact nature results its development that respect the hinterland, and sufficient densed to cause increased walkability and induced 'breathability' or increase wind flow across buildings and urban structures or blocks. The nearness and availability of water enables the buildings and urban spaces to benefit from a cooler atmosphere, cause enhanced comfort conditions in the outdoors and public spaces, and these also support a greater variety of plant and animal life, the additional local humidity due to evaporation usually creates a microclimate supporting unique types of organisms.

\subsection{Mapping selected sites and typologies}

Based on availabilty of information and across each case study city (Melaka, Palembang, Pontianak) representing sites in Malaysia, Sumatera and Borneo, supported by smaller centers such as Kuala Kangsar, Alor 
Setar and Banjarmasin. These are argued as sites that constitute the indegenous or pre-colonial urbanised core patterns of the same scale and size are studied and reconstructed from historical documents, travelogues and cartographic documents. Both architecture and urban core patterns are modelled and measured drawings simplified. In some cases, past configurations are estimated when post-colonial elements are erased to unearth the earlier layer. What are similar between these sites are that they are maritime densed centers located at littoral or coastal sites. These 'negeri' (Reid, 2012) based cities are contrasted with 'nagara' based gridded cities which refer to more 'gridded', 'mandala' based agrarian settlements are particularly well-known for their essentially ordered or 'semi-gridded' layouts and cardinal-based arrangements (Angkor, Majapahit, old Palembang city) (see Figure 1). Urban cores of 'negeri' (or maritime) based settlements evolved following the gradual disappearance of the 'nagara' ceremonial centers and civilisations by the 13th to 14th centuries. Many of these maritime centers grew at a rapid speed along the littoral due to trade-based activities within the archipelago and have been perceived as disorderly, densed and organic, located either at confluences of two rivers or at the mouth of large rivers, but which, on closer study, contain themes and theories which can be brought into an overall framework of urban design theory for sustainable urbanism based on context.

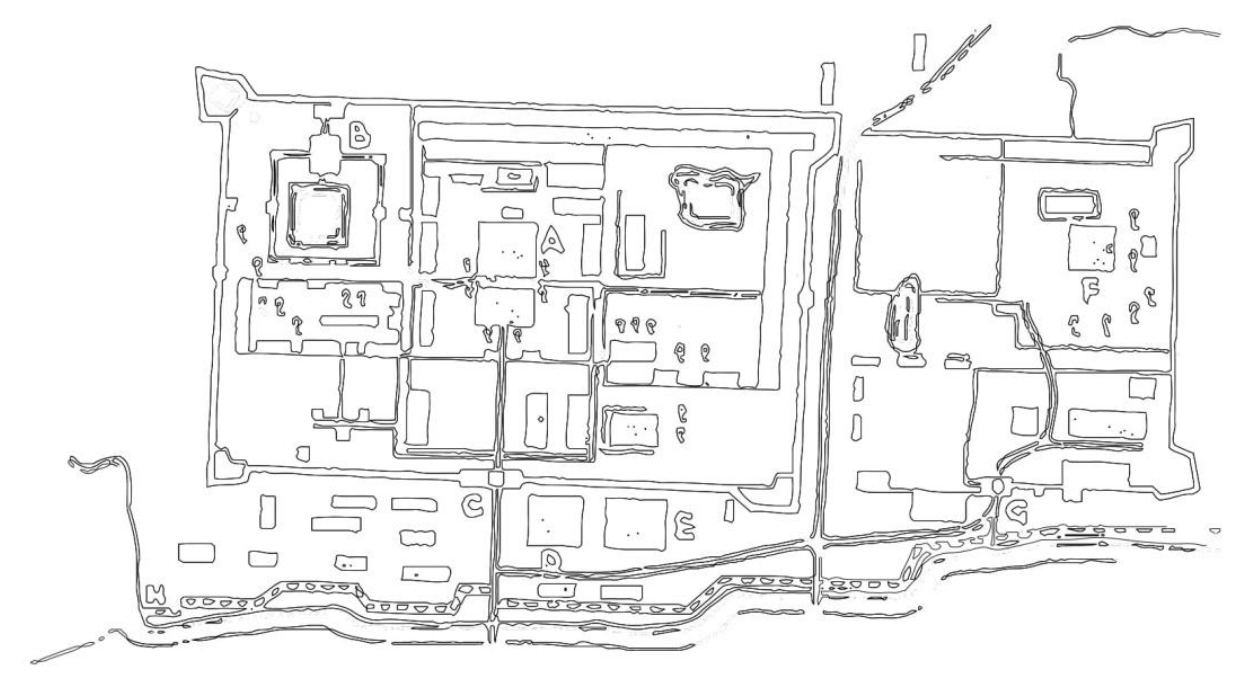

Figure 1. The gridded forms of Palembang fort refer to external influences onto a local pattern city, a 16th century fort and externally impacted patterns from a Majapahit influence. (Source: Major William Thorn, Indie Cultureel 1939).

Using past maps and cartographic sources, supplemented by descriptions by travellers and reports are historical text, morphologies are reconstruction, past researches and modelling techniques, three centers are used to compile patterns of the past based on 1) landscape 2) urban form and 3) architecture and urban core patterns. These are collated in terms of textual descriptions and which represent certain era of these centers, eras which are argued which have not been impacted by outsides. The pre colonial centers reconstruction in terms of estimated morphology and elevations are 1) Melaka; 2) Palembang; 3) Pontianak and 4) Alor Setar. In some cases, the old sketches are taken to verify the estimations.
The case of medeival Melaka in particular, is remarked by Portuguese surveyors for its cool environment amidst tropical heat. It essential planning forms a kind of mirror axis, i.e. the Melaka form is reflected across the Straits and South China Seas into selected cases of palatial centres of tropical civilizations which constitute the same culturally-rooted yet climatically-benign region 'mirrored' across the seas.

\section{Discussion and results}

\subsection{Description of key sites}

Melaka was a center that grew due to its strategic location astriding a wide navigationable river with a nat- 
urally-occuring ‘fort'. Melaka was a Malay 'kedatuan'- a royal based maritime South East Asian city that strategically grew midpoint between "the turn of two monsoonal winds" and at the mouth of a large navigational river and deltaic plain, allowing ships to easily navigate and birth. The hill became the 'royal' site which was bordered by orchards and a large field and then a densed community represented royal enclaves, followed by other structures including mosques and artisan neighbourhood (Figure 2a, b and c) and on the opposite side of the river was the commercial area. The open green area represented direct administrative apparatus and support structures under the monarch in the era of medieval maritime cities or river-based cities which grew at the confluence of rivers. Over time, it has evolved into a more structured, more axial character and the original old city. Figure 3 shows how across centuries sedimentation had continued at the river mouth and the shoreline has change. Figure 4 shows the evolution of the Melaka city from the original pattern of Melaka has been attempted to be reconstructed by Jahn Kassim and Kamariah (2018), and Widyamoto (2016) etc.
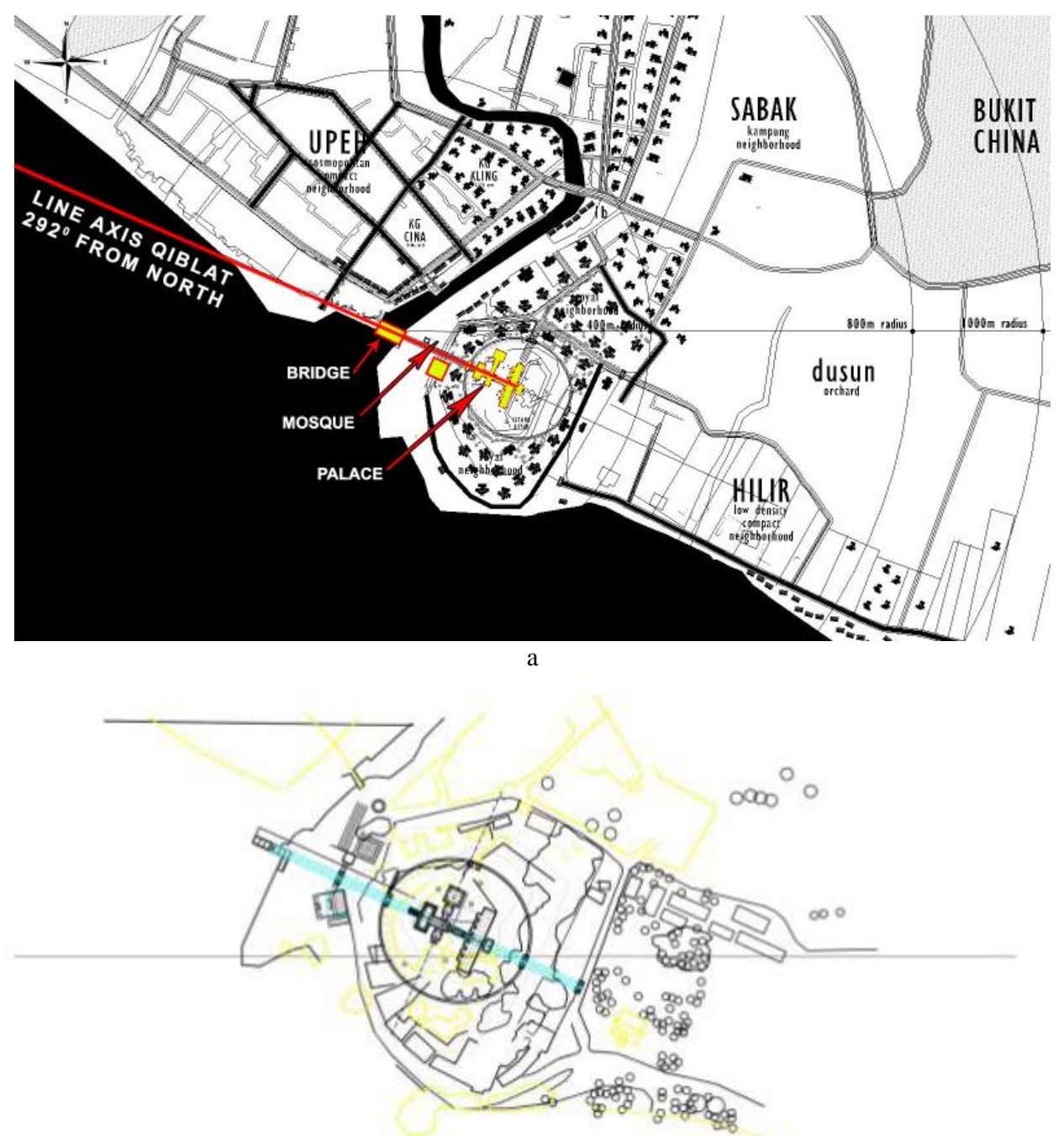


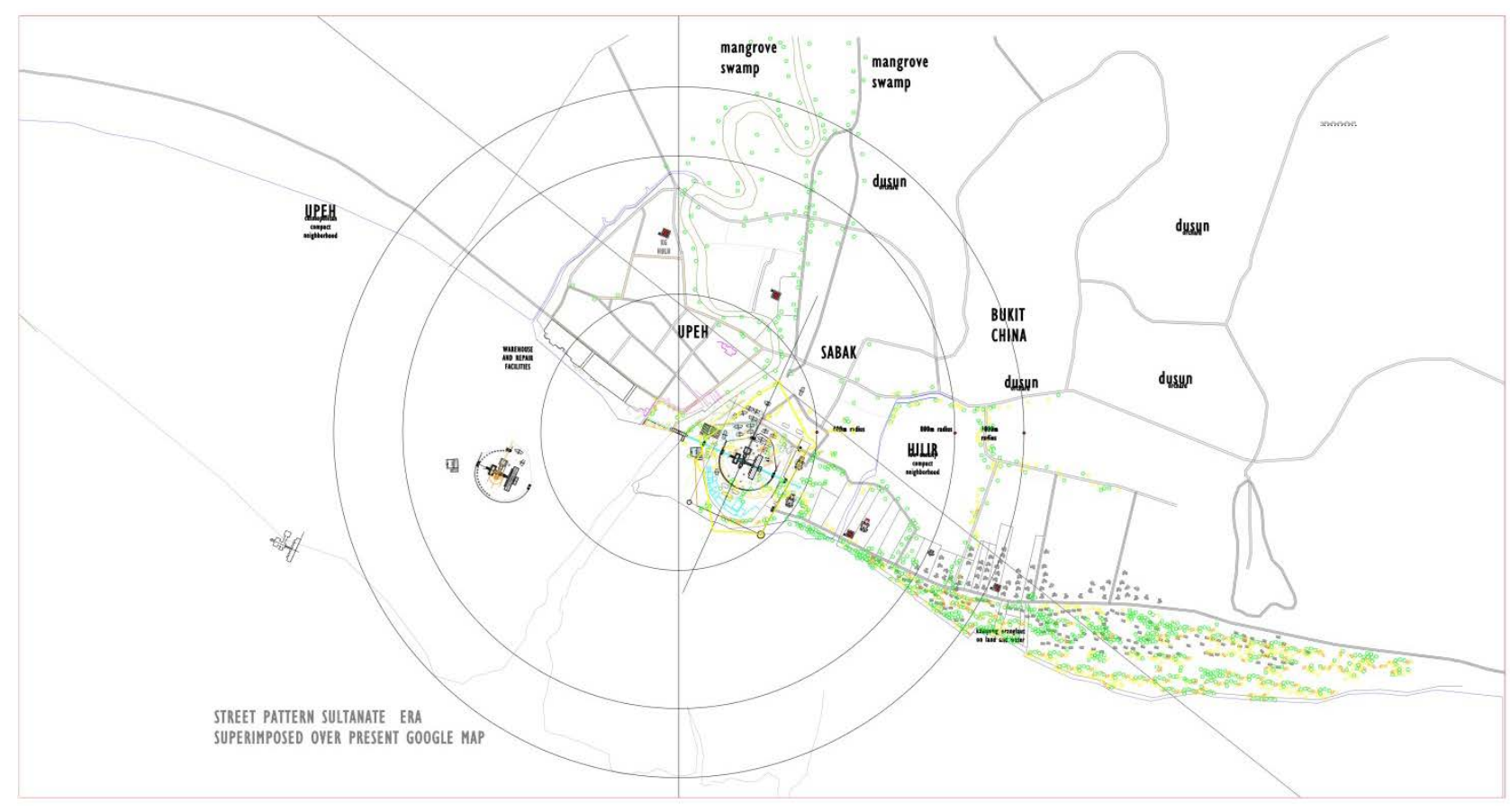

C

Figure 2. Morphological Reconstruction of the precolonial indegenous Melaka port city, showing an archetypical pattern reflecting the organic vernacular-based in the littoral configurations which gravitate along river and coastal line around the traditional palatial core. (copyright: Kamariah Kamaruddin).

\subsection{Pontianak, Kalimantan Borneo, along the Kapuas River}

Found along the river Kapuas, it evolved as the capital city of West Kalimantan. The city of Pontianakn evolved at the confluence of the Kapuas river which is in total, 1,143 km (710 mi) long and up to $700 \mathrm{~m} \mathrm{(2,300} \mathrm{ft)}$ wide at its delta; with a total area of $98,740 \mathrm{~km}^{2}(38,120$ sq mi), the river basin covers more than $67 \%$ of West Kalimantan. The river originates near the center of Borneo, south from the Indonesian-Malaysian border, in the joint between the western slope of the Müller Mountain Range, which runs through the island center, and the southern slope of the Upper Kapuas Range (Indonesian:
Kapuas Hulu), which is located more to the west. For about several km (103 mi) it flows through a mountainous terrain and then descends to a marshy plain. As river discharges into the South China Sea, it forms a marshy delta, and the delta is located west-southwest of Pontianak, the capital of West Kalimantan province, which lies at the equator. The delta has five arms, of which the northernmost one is the widest, and is therefore called the Big Kapuas (Indonesian: Kapuas Besar). The largest tributary is the Melawi River, which occurs to the left near the city of Sintang, about $465 \mathrm{~km}$ from the mouth. Other major tributaries are the Landak, Kubu, Punggur and Sekayam rivers. 


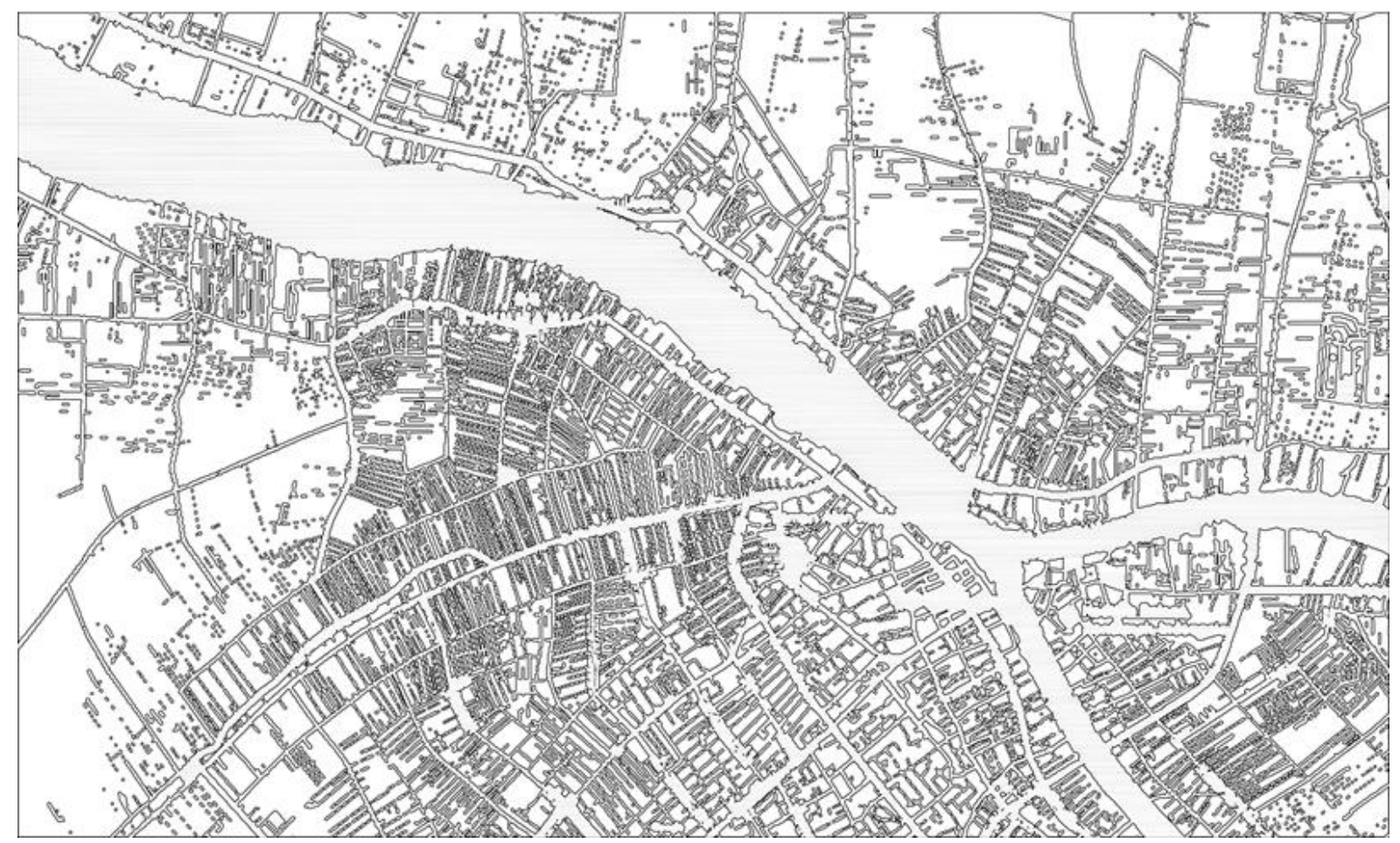

Figure 3. The urban grain of Pontianak city, showing the finer urban grain near the Kapuas River (adapted from Vahid Moosavi, 1984).

\subsection{Palembang, along the Musi river}

Recalling Tarling (1999; p. 197) description of how traditionally the indenenous saw their worldview, which gave rise to its urbanism and settlement patterns is particularly crucial: ' ....In the traditional Malay view of the world there was a powerful duality, a landscape dominated by high and steep mountains and seas whose horizons seem unreachable...' The old Fort Kuto, has the hill as a background and river in the foreground, the movements. Yet before the fort which was the outcome of the influence of Majapahit, there was an ancient capital of Palembang which was a royal center which been an important trading centre in maritime Southeast Asia for more than a millennium. There is presently no document of this center except for the sketch in Figure $\mathbf{4}$ but it is known that it flourished by controlling the international trade through the Strait of Malacca from the seventh to thirteenth century, establishing hegemony over polities in Sumatra and the Malay Peninsula. Across its sites, Sanskrit inscriptions are found suggesting the ancient age of this river-based city and Chinese travelogues report that the kingdom prospered as an intermediary in the international trade between China and India. The nature and directions of the Monsoon, or biannual seasonal wind, had facilitate this city as a port of call where traders would sojourn there for several months waiting the direction of the wind changes, or had to go back to China or India.
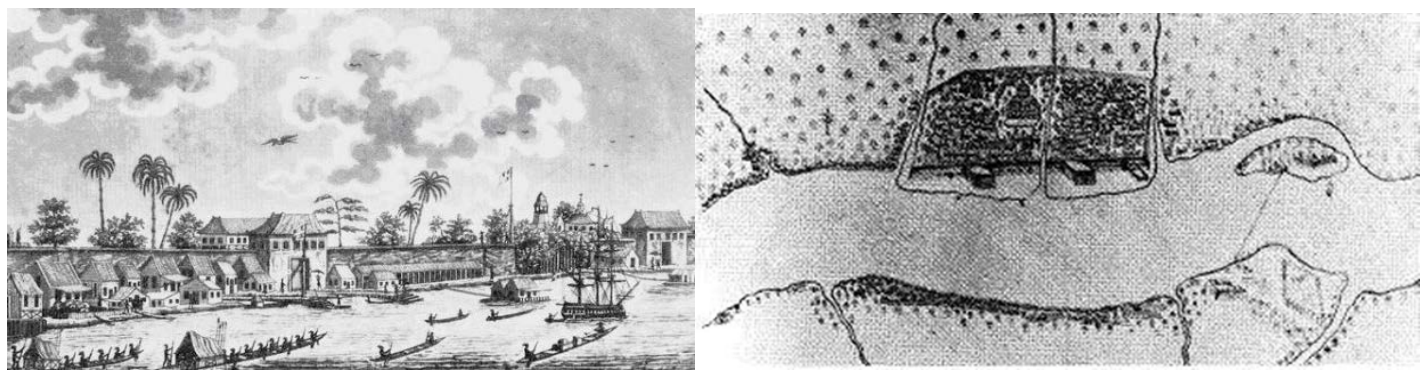

Figure 4. A sketch of the Palembang littoral urban center before it was burned down by the Dutch in 1659.

Fitri and Triyadi (2015) described the essential life force of the Musi river as a force determining the urban- ism of Palembang. This city is perhaps a sample of what was aptly describe by Fahan et al. (2018): River net- 
works play a key role in the spatial organization of human settlements. Both river networks and human settlements have been found to exhibit regular self-similar patterns, but little is known about the generalized spatial patterns of human settlements embedded within river networks. ... The closeness to water activities made those people maintaining the sustainability of the river (Santun, 2010).

\subsection{Supporting sites}

Due to the decimation of Melaka, Kuala Kangsar, because it is a splinter of the Melaka royal pattern, and the precolonial urban core of Perak was centered at Kota Lama Kanan (see Figure 2a and 2c) as the first royal centre of Perak (1528). Its original palatial core was known as Istana Sri Sayung. The remnants of the royal center suggests an image of a royal neighborhood of which to the left is where the istana complex could have been indicated by bamboo reed fencing, with the residence of the kerabat diraja - royal families within close proximity and the mosque centrally located, bounding the padang in front of it for easy access from the river as a public assembly area. The river then was very much part of the Malay economic livelihood, as a source for food as floating marketplace and as communication and transport highway. F. McNair (1887) had described the villages of Perak, as the urban centres situated on various river (1.2e and 1,2g) and Sungai Perak as the highway to the sea, became the means by which the people obtained the supplies.
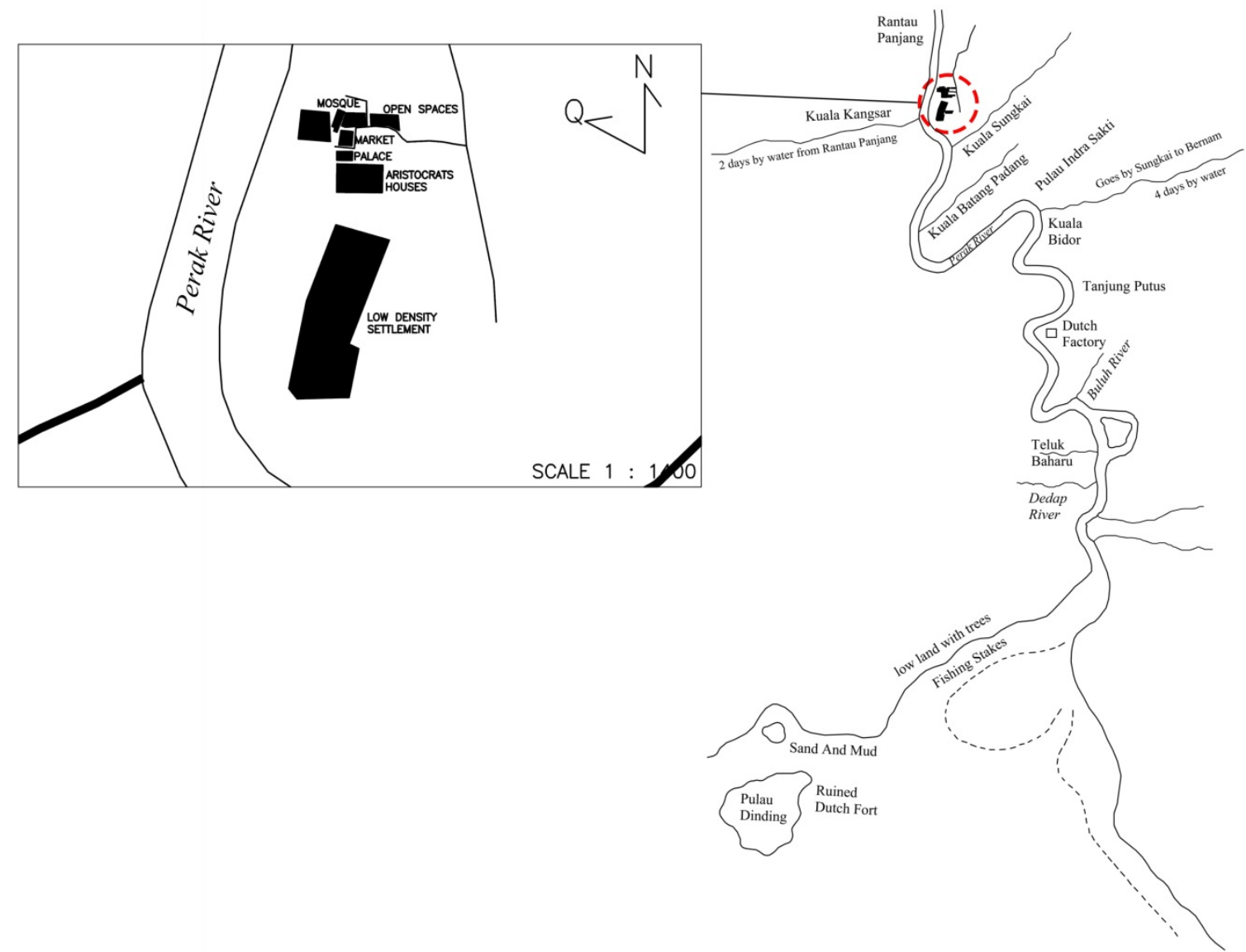

Figure 5. The Mapping of the first royal center of Perak, Istana Seri Sayung (1528) at Kota Lama Kanan, an estimation of orientation and configuration which grew around the confluence of two major river courses. (source: Illyani Ibrahim, 2018).

The city center of Banjarmasin has been changed several times due to its geographical location, colonialism and conquest. Since the Banjar people are highly dependent on the Borito River and Martapura River as their main transportation network system, therefore, the settlements and human activities were always close to the river and concentrated there. As water reservoirs and suppliers at high tide, these canals play a role in control- 
ling the water overflow and avoid flooding. In the past, the canals also used for defense, which built around the fort as found in the Tatas Fortress. The population of Banjar know three types of canals; i.e. the Anjir (also called Antasan) which is a kind of primary channel that connects between two rivers. Anjir functions in the public interest with the emphasis as an agricultural irrigation system and means of transportation. Secondly, the Handil (also called Tatah) is a kind of channel whose mouth is in the river or in Anjir. Handil basically functions to deliver water to the agricultural land area. It is smaller than Anjir while the Saka is a tertiary channel to channel water, which is usually taken from, and is smaller than Handil and is family or private. According to Schophuys (1969), the canals in the form of Anjir, and thus the city of Banjarmasin is based on the name of the river and its subsidiaries, such as Sei Jingah, Sei bilu, Handil Bakti, Antasan kecil. Thus, a total of 102 rivers that flow along Banjarmasin and these incredibly intricate network of rivers, streams and canal form a unique character of the city. Over centuries, the settlements and its activities are always close to the rivers, so that many heritage sites are on the banks of the river. Heritage sites, traditional buildings, culinary and community activities on the river banks are accessible by public transportation.

\subsection{Urban design themes - archetypal forms}

Based on the above, it is argued that the character of serenpidity or pleasant encounters is a combination of planning and architecture principles were arised from a series of common recurring patterns. These urban vernacular forms of these urban centers allude principles sustainableurban design which can be constructed and further expanded as guidelines. These are accretion, river gravity, fractality, centricity, and a verandah city or 'shaded' city.

\section{(1) Accretion}

Accretion can be defined as 'a growth or increase by the gradual accumulation of additional layers or matter'. Sanders and Baker (2016) make reference to 'accreted patterns has been a strong foci for urban morphological study that conceptualizes the urban landscape' ...Boeing (2019) usefully defines and refers to accretion in the case of “...Street networks may be planned according to clear organizing principles or they may evolve organically through accretion, but their configurations and orientations help define a city's spatial logic and order....”. Basically, accretion or accretive patterns occurs within cities which are planned without a grid-as well as unplanned cities. In these cities, the urban patterns grew through accretion-and may lack clearly defined orientation order, but can still be well-structured in terms of complex human dynamics and land use (Hanson, 1989). Specific visual/geometric order should not be confused for functional/social order... Accretion is thus the gradual accumulation of form which in most cases, result in finer urban grain around and near the water sources or routes. 


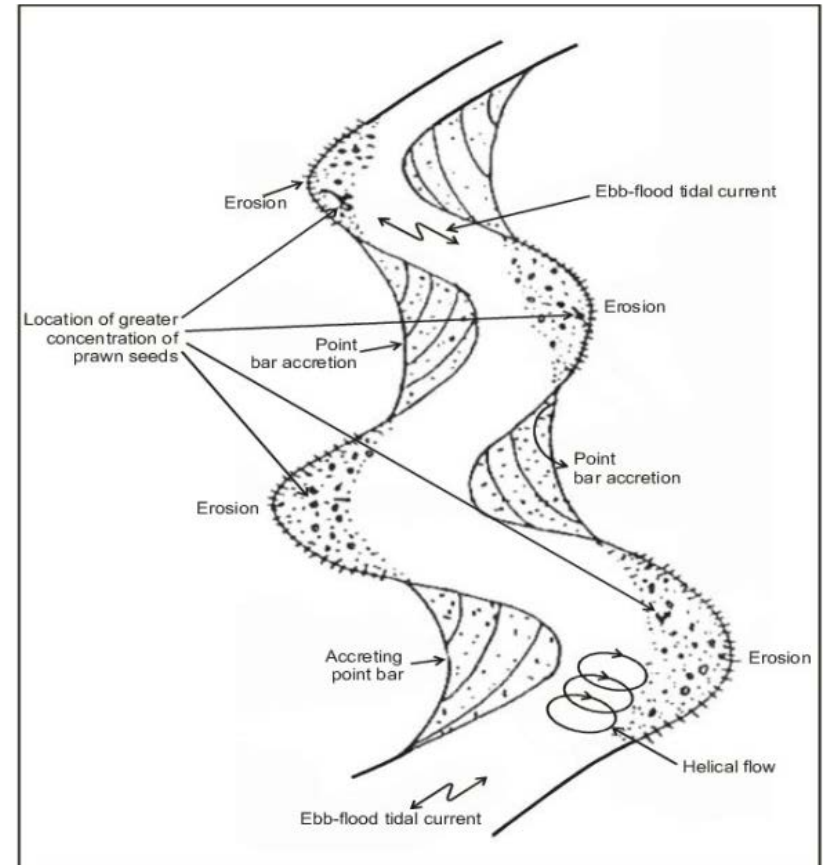

Figure 6. The definition of acretion as a topographical and geographical phenomenon. (source: Kumar Das and Siddhartha Datta, Man-Made Environmental Degradation at Sunderbans, Reason-A Technical Journal. January 2014).

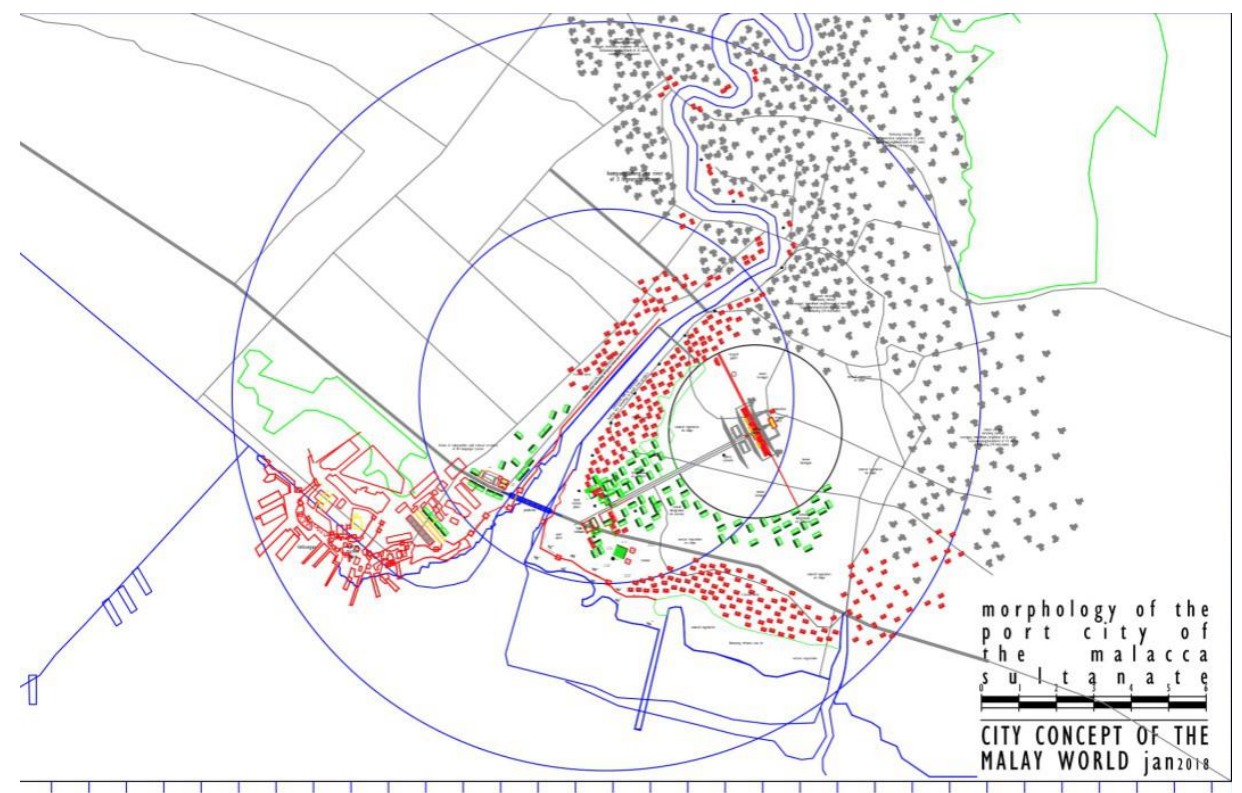

Figure 7. Morphological reconstruction of original vernacular urban configuration of Kota Melaka through textual and cartographical sources showing 'accretive’qualities (source copyright: Kamariah Kamaruddin).

\section{(2) River gravity}

The river in the South East Asian archipelago is particularly meaningful and powerful agent in the past,shaping not only physical, but perceptual and cosmological outlooks towards their environment. As described by Andaya (2008; p. 22) “... the people were named after a particular river or stretch of river, stream or coast. In this maritime world, rivers and seas formed unities, while land formed the link between bodies of water ...” Furthermore, in modern context, the physical and spatial structure of historical area can promote the identity of river city. As the old riverside settlement is the first origin place of city, the existence of this area also has historical value and meanings to the citizens. Historically, ethnographers have categorized settlements or civilizations in this region, before the $13^{\text {th }}$ century as 'inland' or 'nagara-based', and after $13^{\text {th }}$ century or the arrival of Islam as 'coastal' or the 'pesisir'. With inland 
civilizations, they are characterized by a central, mainly masonry based early civilization, spread across large inland area, with strong and ordered center, while the 'coastal' civilizations have often been described as 'ungridded' and 'disordered'. Tarling (1999; p. 197) usefully defines a conception of how the South East Asian maritime populations saw their environment:

'...In traditional... belief, both the source of river waters and the home of ancestral spirits were high on the mountain slopes; the highest reaches of the mountains were thus thought of as holy places and the source of beneficent forces that bestowed well-being upon the people.

...The critical link between these two forces of mountain and sea were the rivers, for they were the channels through which the rainwater that fell on the mountains flowed down, ultimately to merge with the sea. These river basins contained the earliest polities of island South East Asia ... 'and shaped the political dynamic between them;'

As morphology become increasingly crucial in the search for culturally-rooted, to unearth the urban grain, density and the urban structure of pre-colonial times, have particularly been crucial. The River, as well as other physical urban elements, thus constitutes a key acculturation pathway and strategy and thus has important indications to a more sustainable pathways of development, design and planning.

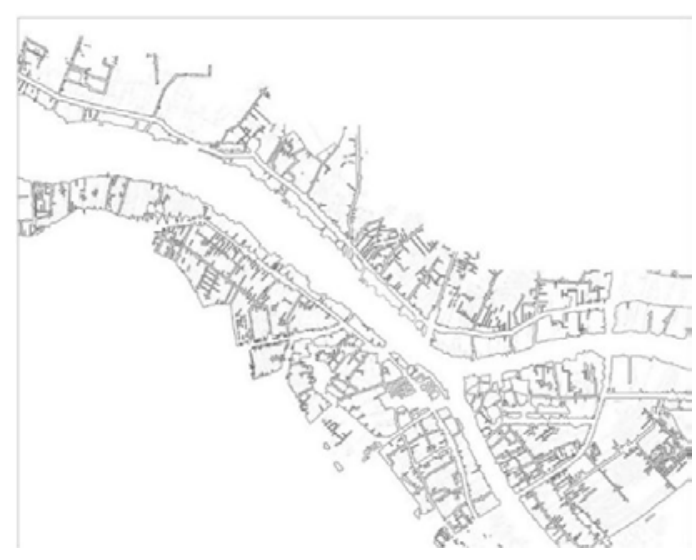

Figure 8a. The simplified urban grain of Pontianak showing the gravitational pull of the Kapuas River network.

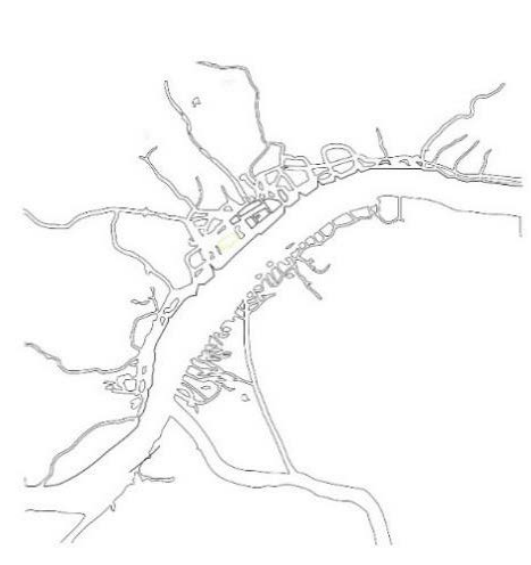

Figure 8b. A simplified grain of Palembang with a focus on the river-based patterns and grains reflecting the earlier patterns of the 1800 s.

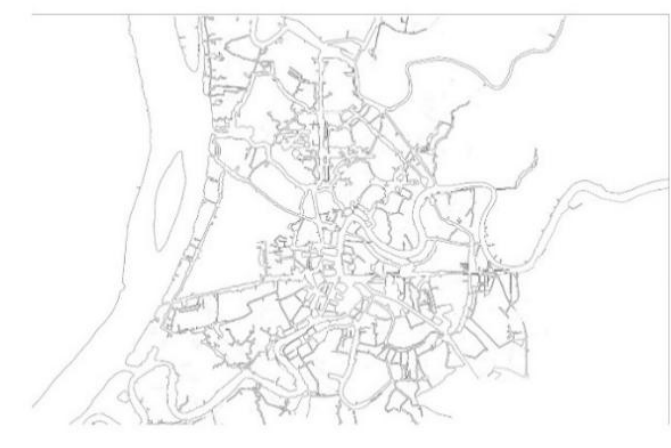

Figure 8d. The interlocking river and canal network of the Banjarmasin city, Borneo.

Figure 8c. A more recent
urban grain in Palembang.

The public realm is thus inclusive of the open spac-

es along the water way of Sungai Perak (Figure 5a) 
which represented the public highway then; where most of the economic activities took place. These are partially on boats, and thus which had produced an 'acretion' community of the floating market. What was a scene inseparable from the Sungai Perak during precolonial times, is no longer there and has been destroyed by development along the river. Figure 9 highlights the main pathway that parallels the river from other village centres strung along the river upstream and downstream which lead to the padang of Sri Sayong; bounded by the natural landscape that form the back drop of Sri Sayong and the interfacing elements that include 1) the fencing surrounding the istana and its gateway entrance formally facing the padang expressing the centrality of the istana. 2) the intricate bamboo side wall facade (palm and bamboo are the chief village building materials (F.McNair 1878). and 3) the anjung - portico of the istana to receive guests; directly opposite the gateway suggesting focal intent of the public realm.

Tarling (1999) represented how the Malay populations traditionally saw their ecological environment and its meaning: 'the sea offered countless options for people who were at home in boats and where agriculturalists were dispersed in many small riverine enclaves'.

There is a close relationship of the social culture of aquatic communities in the South East Asian archipelago and the nature of their river eco-systems. Traditionally atterns of settlement are formed along these rivers and these crowd densely around river banks and river mouths. Based on it, the concept of riverbank settlement could be developed by modifying the patterns on the river. The river and the sea was the source of daily water, fishery and trade transportations. The settle-ments were built along the wetland on the river bank that directly connected to the river transportation. The riverfront houses had two faces with the main face was directed to the river. Formerly, each riverfront house had a terrace with boat dock. The houses were connected by long bridges on stilts. The houses stood on the wetland that was always inundated, therefore, it was built on a stilt or rafts foundation. Originally, past settlements based on these river functions not only determines the distance of the buffer area, but also the orientation of the buildings. The settlement orientation changes gradually from the upstream to the middle until the downstream. The settlements in the upstream zone are not oriented to the river. The lay- out of the building is adjusted to topography and circulation path of the land. In the middle zone, every riverfront house has two faces with the main direction is to the land. While in the downstream zone, the riverfront house has two faces with the main orientation to the river. It indicates that the higher the level of river dependence the more the settlement will be oriented to the river. People's dependence on rivers influence their adaptation manifested in the typology of the building. In the upstream where river functions have little effect on people's lives; people avoid the erosion by keeping away the settlement from the river banks. The vernacular settlements had a concept that flexible to the natural cycle of the river ecosystem. The evolution of building technology and the river ecosystem damage reduce the community dependence on the rivers. It also shifts the community perception on the natural cycle of the river ecosystem from sources of life to disasters.

(3) Fractality and centricity

Fractality is argued as a necessary factor in serendipitious conditions. This represents an organic or fragmented geometry of planning and configuration is where objects of the same shape exists at all scales despite their irregular appearance. Its originator, Benoit Mandelbrot (1983) found that are objects of any kind whose spatial form is nowhere smooth, hence termed 'irregular', and whose irregularity repeats itself geometrically across many scales. Such irregularity of forms occurs not only in the very 'small' but the 'very large' such as planning of vernacular settlements and cities where fractal patterns have been observed at city and settlement scale. It arose in the midst of the advent of chaos and complexity theory in the mid-70s. Departing from the theories based on non-Euclidean mathematical concept describing the complexities present in the nature in simple terms, the birth of fractals can be traced back to 1960s (Zarhami, Olfat, 2015). The fractality of settlements and vernacular patterns, including its more densed urban environment and configuration is a quality of the traditionally rooted patterns and urban area From the research and theoretical writings of Batty et al. (1875), the current emergence of organic tropes in planning and their link between sustainable indicators and an organic method in plannings has seen the rise of studies in fractality. Eglash (1989) first noted fractal structures in aerial photos of African villages. In Ba-ila settlement in southern Zambia 
where the scaling of social status is reflected by the scaling in the architecture of each family ring: with geometric elements of a ring shape overall, and a status gradient increasing with size from front to back - echo throughout every scale of the Ba-ila settlement overhead view of a single house.

Kiani and Amriniparyan (2002) had similarly observed the divisions of the Iranian city based on major geometrical factors in the formation of three systems including macro (city), middle (neighborhood) and micro (buildings). By looking at morphologies of sections of the cities of Isfahan and Yazd, they found three broad features of similarity, iteration and change in scale. These features lead to formation of diverse structural patterns with a similar origin in macro and medium scales, and different formal (ornamental) patterns in the micro system of buildings. Basically, triple features including similarity, replication and change in scale act as a generator and developer and are capable of embedding every geometrical cell in a systematic and complex mechanism as an inseparable part in a comprehensive structural, spatial and formal system.

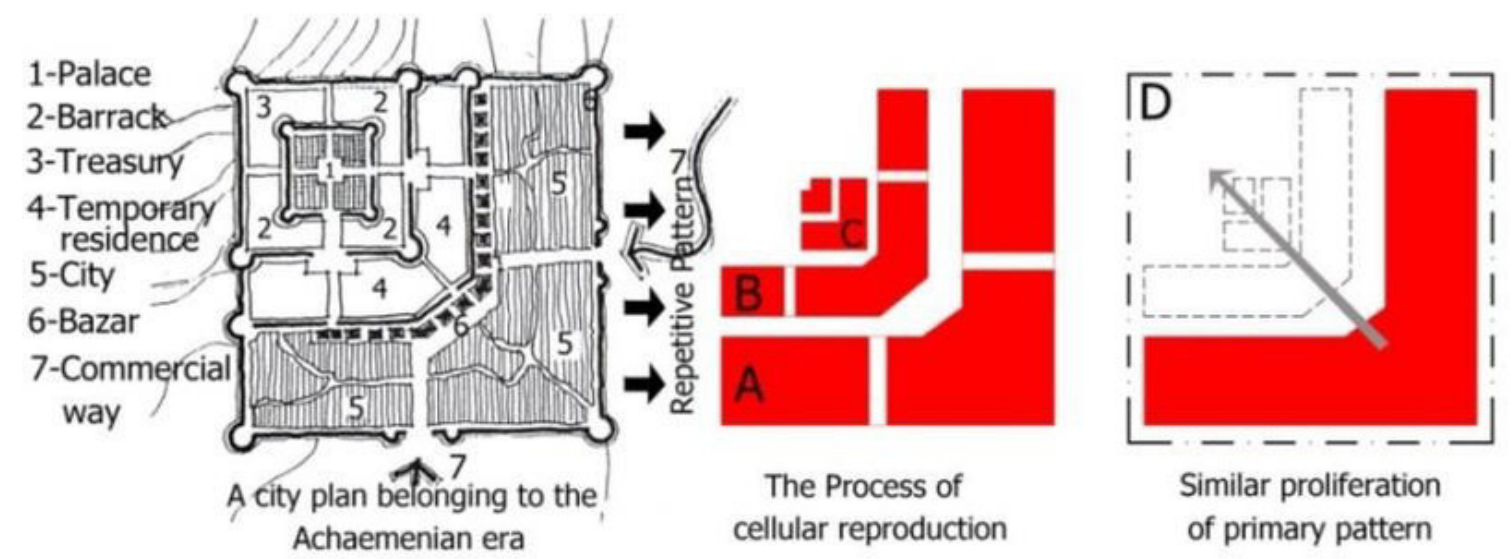

Figure 9. The fractality of traditional urbanism in Iran (Kiani, et al. 2002).

In the case of the Malay village, and city, this exist as a fractal pattern from village to city. From the microcosmos mapping studies by Murtaza et al. (2019) (Figure 9b) show the smallest unit of the Malay kampung or village is a cluster which show a ' $\mathrm{C}$ ' like formation, signifying the intimacy of the communal pattern. At a large scale, Zalina Harun et al. (2019, 2020) who mapped the vernacular patterns of settlements in Kuala Terengganu found similar $\mathrm{C}$ formations and the settlement seem to be comprised of these communal formations arranged in random order. In this regard, in principle, although producing a fractal pattern and its extension has a complex structure, it is systematic and whole-oriented. 


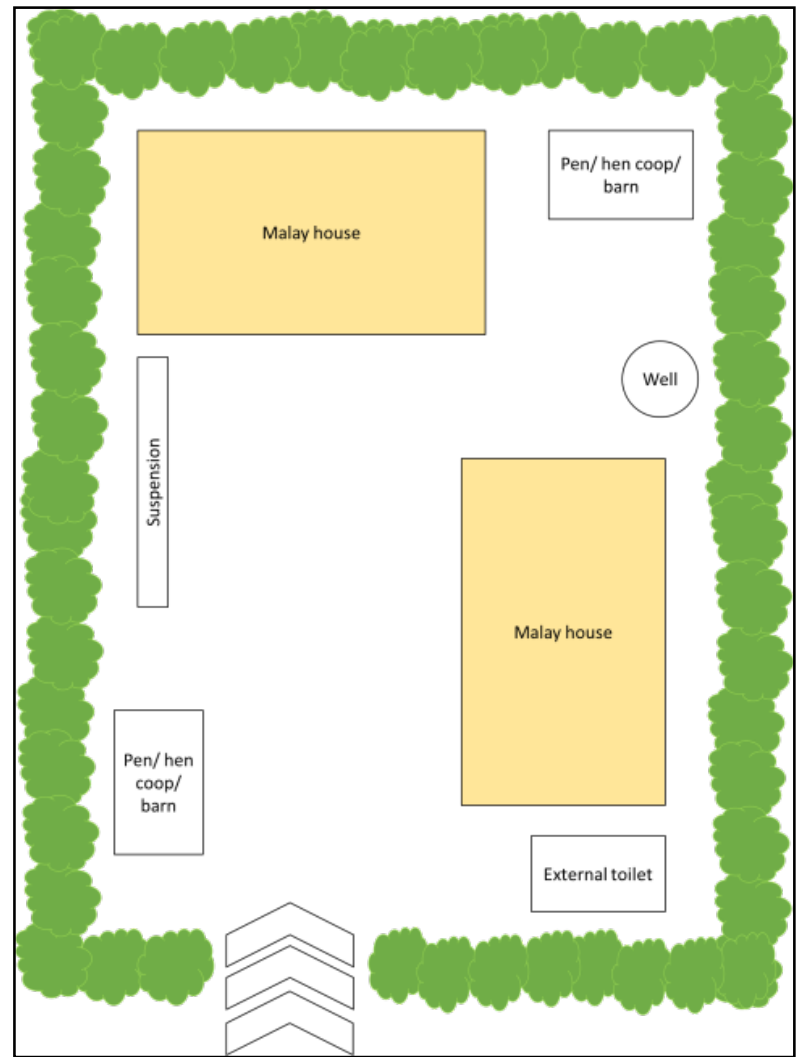

(a)

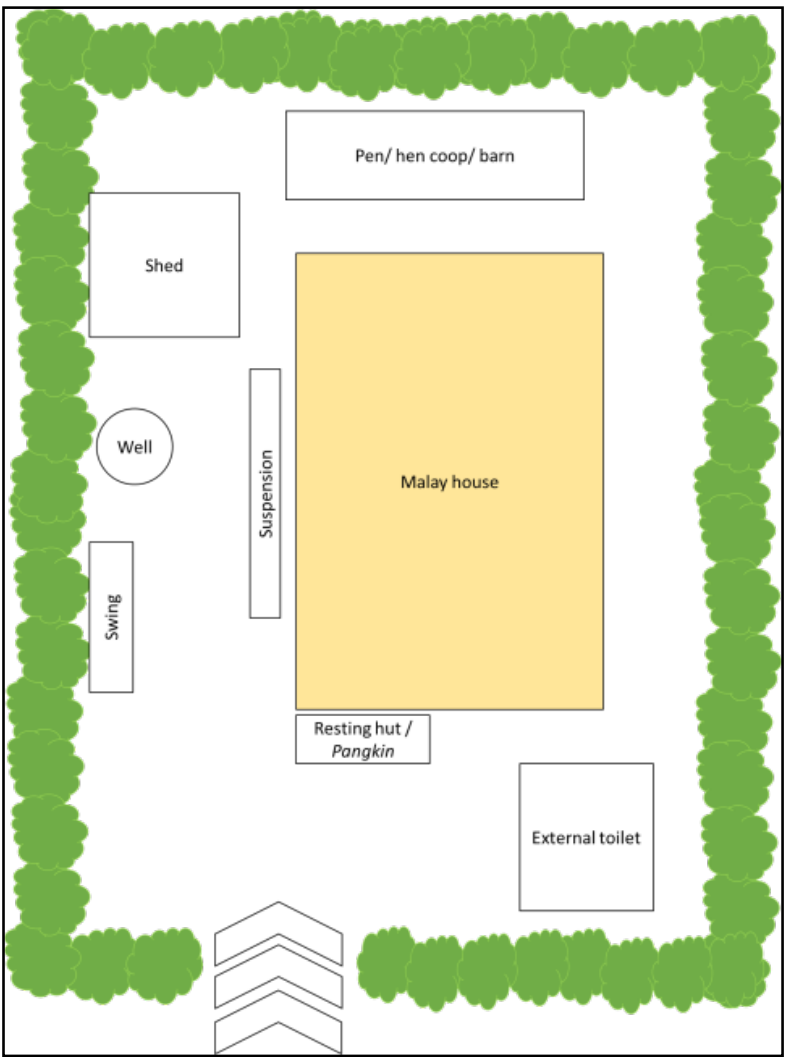

(b)

Figure 9b. (a) Malay traditional archetypical compound for sharing compound; (b) Malay traditional house archetype for single-owned house compound (from Murtaza et al. 2018).

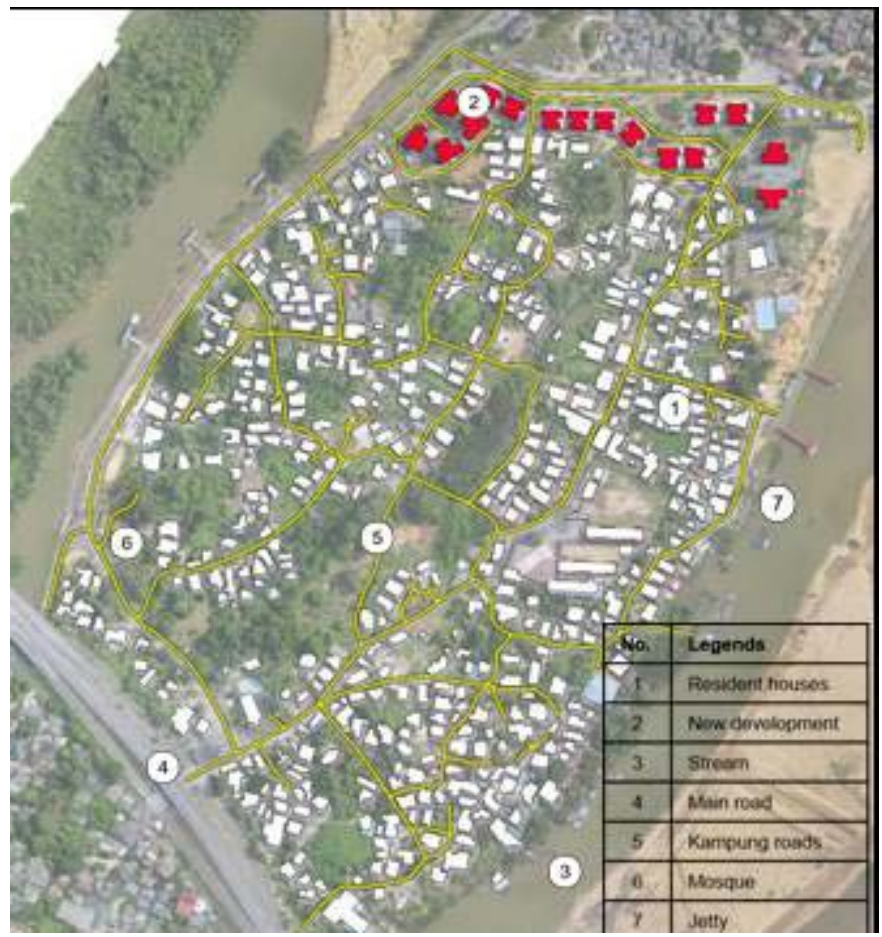

Figure 9c. The layout in Kampung Pulau Duyong, Terengganu Malaysia is physically occurring in an irregular spontaneous way according to their socio-economic activities, culture and belief and way of life as this village almost preserved the physical characteristics of original traditional settlement as identified that wakaf, pangkin, streets and jetty is a place to socialize, play and rest, yet it 
In China, the same fractal configurations are seen in the traditional urban blocks, plots and building fabrics throughout traditional times. These urban patterns based on the traditional hierarchical method of subdividing urban forms, were fundamentally influenced by two policies of past feudal governments, namely, the zoning concept and the 'LiFang' system. The concept of zoning was at the time, meant to separate the noble class, humble class and different kinds of handcrafts industries, as determined by the feudal social hierarchy. The LiFang system was a system of social ordering where a city was divided into a number of LiFangs or rectangular or square blocks, consisting of 25 south-north-oriented family courtyard houses (Zhong, 1986; p. 218). LiFangs were walled and had four gates each side, and were strictly controlled by government officers during the night until the Song Dynasty. The earliest study resource of urban blocks in Suzhou is a map dated from the Emperor Qian Long’s reign (1736-1795).

Hull (1976) noted, how these large vernacularrooted urban centers were disregarded by the colonialists and the complex fractal nature of these settlements went unappreciated. To accommodate both the automobile and increased population growth led twentieth-century urbanists to impose anti-fractal geometrical typologies. Fractality allows an infrastructure to be sufficiently fine-grained so as to allow many alternatives choices, which generate many alternative paths by permutation. This is the opposite of the consolidation of numerous small urban blocks and streets into a few superblocks and superhighways, a process that severely reduces the number of available paths informal. An urbanism flourishes in the spatial interstices of the city and produces urban phenomena with a potent impact on the streetscape and urban image. South East Asian configuration also reflect fractals at different scale, seminal studies by Mark C. Childs, sees the city as: "settlements are not just the sums of their parts; their poetry and vitality comes from their collective composition-the interactions among multiple designs." He argues that it is these elements that produce not only the physical phenomenon of the city, but an ongoing dialogue of design and creation. On the other hand, the city and settlement fractal pattern is the result of the reproduction of a micro stage from a macro stage, and at the same time, the dependency of such stage has to be in such a way that in case of the removal of a single stage, an overall pattern of development and production still remain in place. Hence in studies of ancient urban forms, the fractal city can be the connection between the unified whole of this structure with its smallest part is a similar, iterative and re-scaled. These can indicate a new conscious approach in spatial planning i.e. towards creating a diverse sequence of spatial cells of the whole and part. The coherence between elements of this urban pattern is a reproductive and replicated process in which the iteration of elements reinforces the pattern.

(4) The 'Verandah-city'

As mentioned earlier, urban archetypal design themes cannot ignore the combination of architecture and planning i.e. its vernacular themes in urban planning and its indigenous architectural archetypes. The South East Asian region is essentially a tropical region, characterised by an intensely hot and humid climate year-round, whose experience by the urban population in public places can only be alleviated naturally by increased shade and increased air movement. Thus, mapping the vernacular architectural archetypes of the region will uncover a variety of verandah or extended portico or public shaded spaces. These range are crucial to re-enact key urban design identity and experience of the tropics by combining architecture and planning in creating both comfort and convenience at the same time. A mapping of public spaces and structures in the South East Asian urban centers, would unearth a rich range of these extended shades which is seen as generous and extended portico types. Yet it is the typologies of these traditional portico which are essentially part of the urban fabric of the past, and they facilitate the public realm by acclimatising architecture and public space to the tropics. These porticoes or verandah types are beyond the limitations and expressions of the homogenous five-foot way in these cities, which is essentially the legacy of Colonial administration, and not a derivative of the traditional indigenous urban realm. Thus the term the verandah city, initially coined by Yeang (1981) is crucial towards the South East Asian urban and architecture transformation, either through changing the frontage of buildings or outdoor spaces. By applying the varied forms which is 
found in Figures 10-18, the urban dweller will experience a definite metamorphosis of urban design as these 'verandah' spaces are essentially social interfaces through design and reveal how planning and urban design is connected by local architecture form. It is only by mapping, measuring and morphing these semi-public and shaded spaces which occupies the intermediate realm or scale between architecture and urban planning, that the character of tropical city spaces, which can be commonly named, as 'third place', can be shaped and devised to precisely facilitate the serendipitious encounters, meeting nodes and public gathering places, which are important for communal and social life to endure and local democracy and a public spirit of South East Asian communities and cultures to live and thrive.

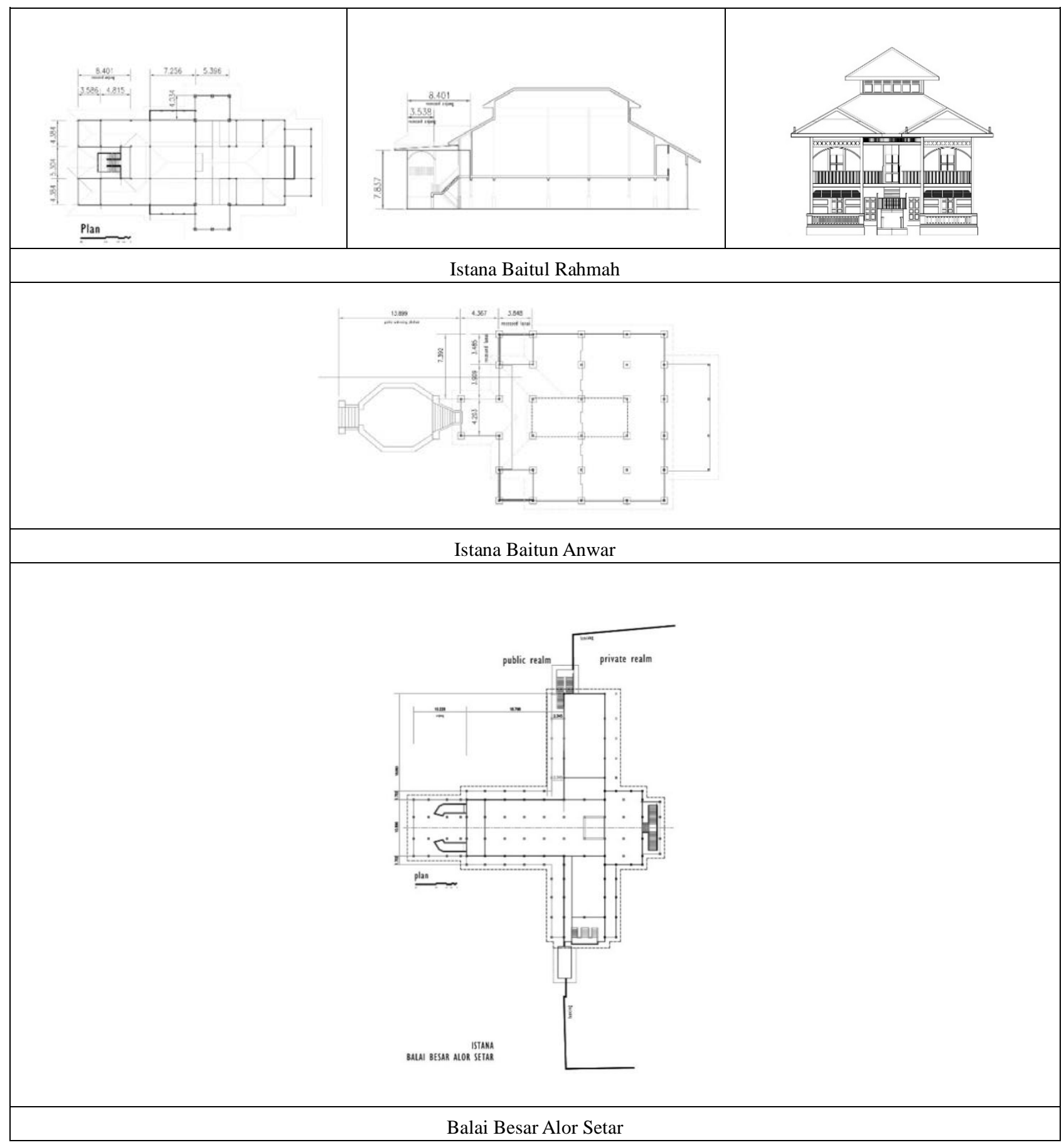




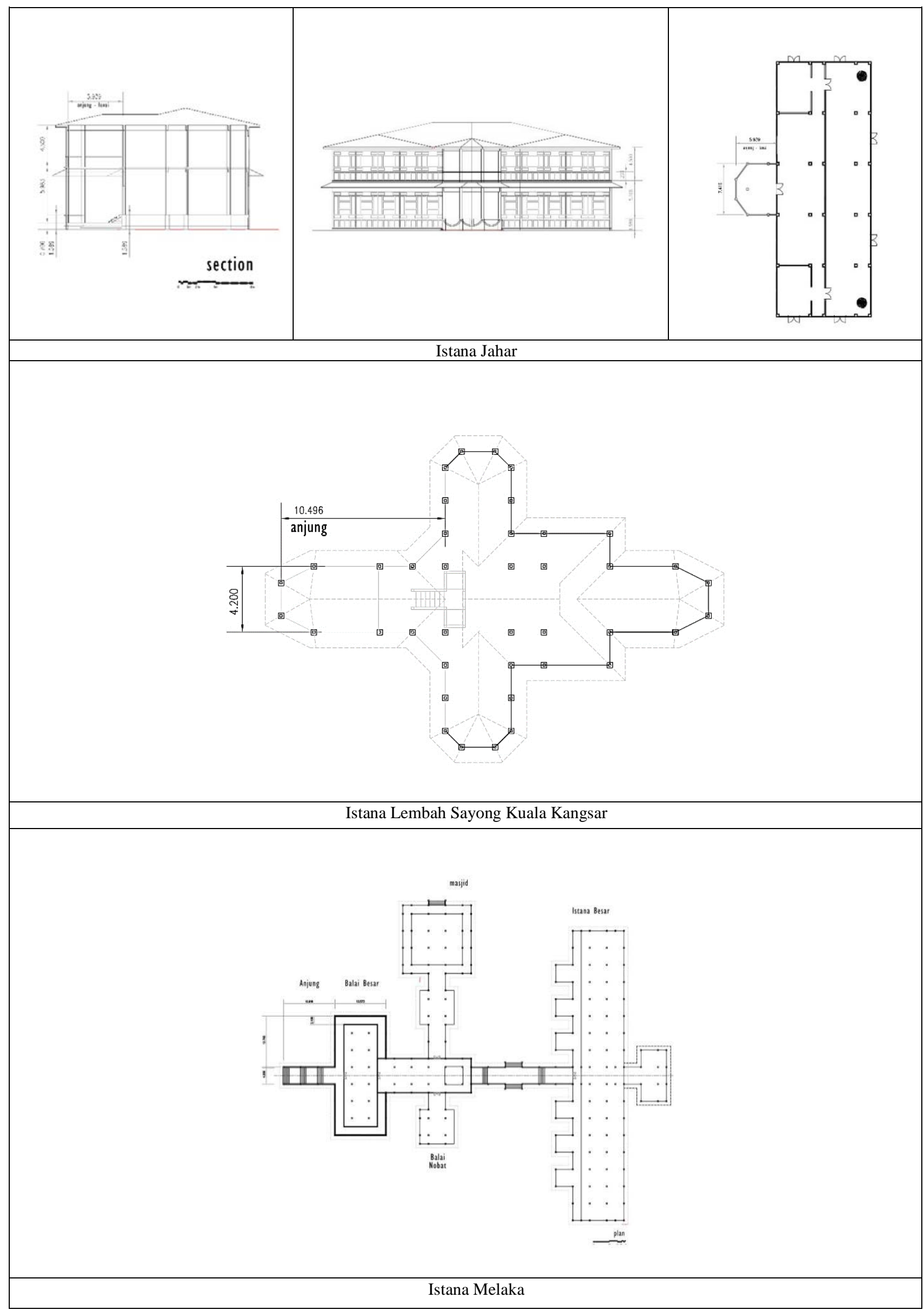




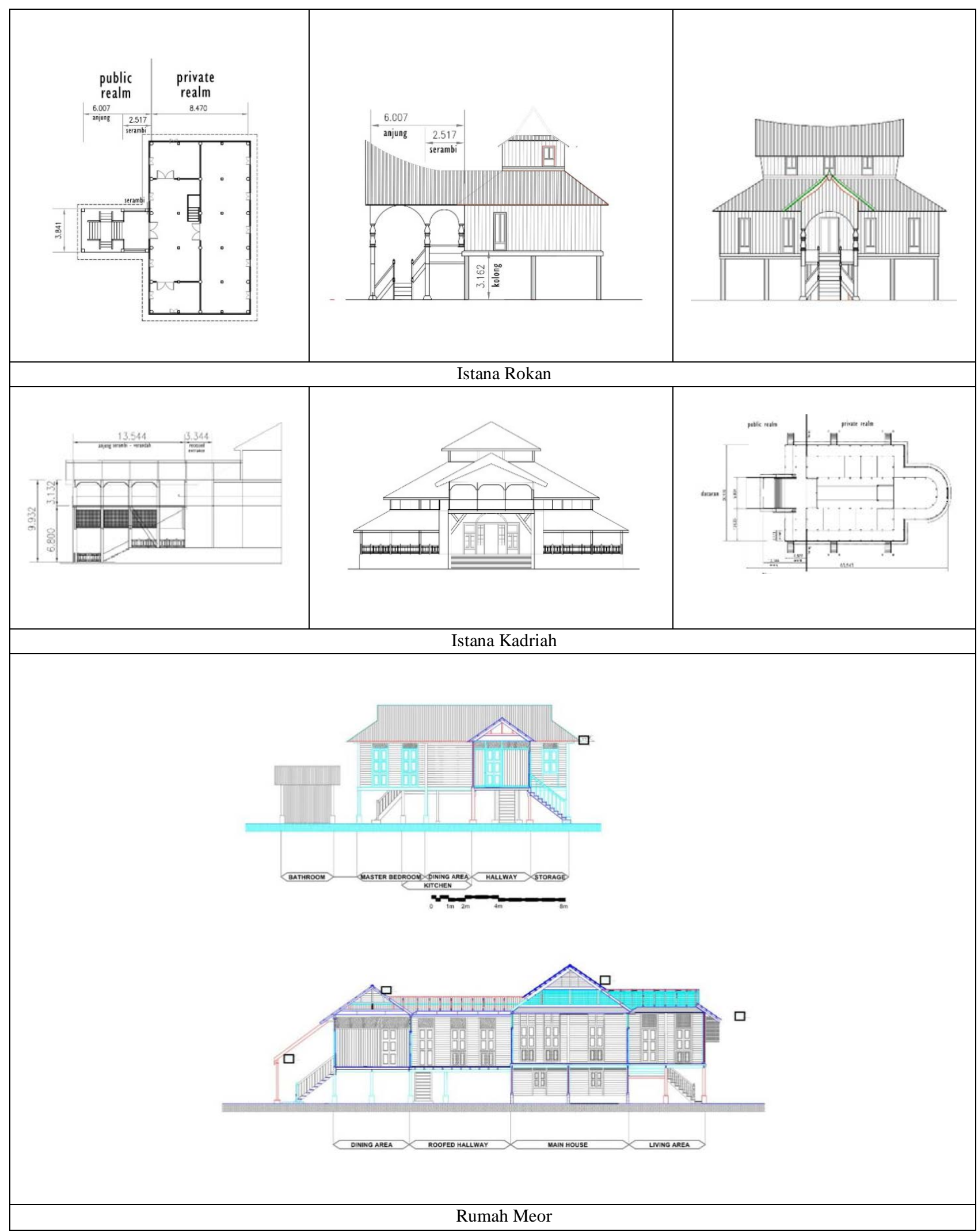

Figures 10 to 18. The Aristocratic structures showing the semi-opened serendipitious tropical portrusions which are wind catchers and spaces which can portrude from the massing of architecture and cool naturally. 


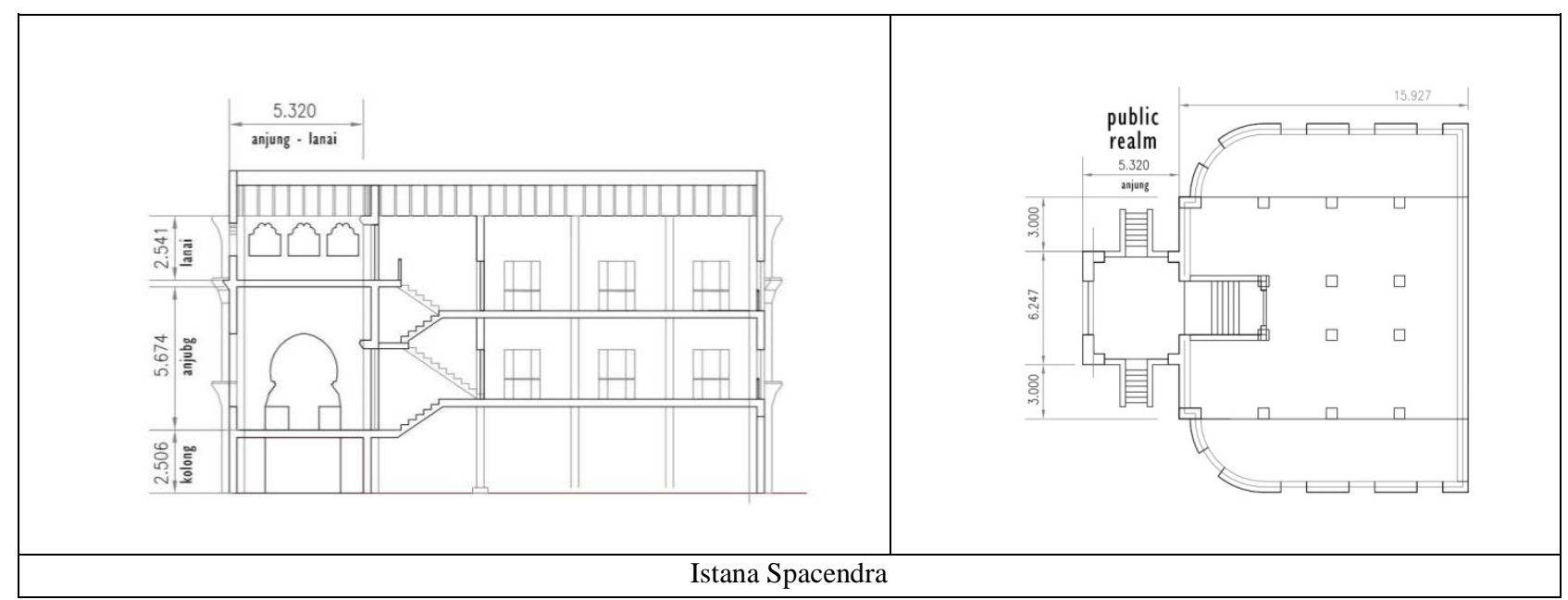

Figure 19. The petrification of the natural vernacular architecture has evolved from timber to masonry yet still sustain the portruding ventilative forms.

A mapping and comparison of public buildings of the vernacular precolonial era in the Malay region of South East Asia, will show similar portrusions and extensive porticoes (see Figure 9 to 13 and Figure 14 above). Past forms of shaded urban spaces are essentially variations of the primal and archetypal verandah-like spaces, whether they are collonaded extensions of palaces and mosques, to the greenery extensions which serves as a shaded continuum or 'glue' that was crucial towards creating permeability in the tropical city. Buildings were not set apart and seen individually, but was part of a network of urban spaces. It is these endless variations and permutations that created the character of serendipity causing the traditional city to be full of pleasant surprises and spaces.

\section{Conclusion}

The quasi-urban indigenous urban patterns are centers which are densed, containing urban patterns such as commercial areas which are organic yet due to the archetypical principles, have an innate comfort and livability. Based on the patterns, a series of principles are outlined that describe the patterns and their innate characters are discussed. The climatic factor in the tropical region is a powerful driver, and has constantly exerted influence on the region's public spaces. Each element and space within the structure had a predetermined and assigned function. The marriage between architecture, climate, ecology and form as it had grown from the very location and climate within which it was bred. Expressive variations can be developed in large structures assist in the cooling of urban spaces, while ventilative cooling and wind-driven comfort can be achieved through the interactions of such linear, narrowly planned forms of such shaded areas. These traditional spaces also include how ground floor spaces which flow unrestricted underneath buildings not only cool the spaces above but were used for multiple purposes. In modern buildings, architects such as Ken Yeang had attempted to re-enact such spaces in the city, yet modern elements create a quality of openness and austerity, in comparison to the richness and collonaded spaces of the past. Until today, such uninterrupted spaces of ground floor spaces are characteristic of the s interlinking spaces with multivolume heights in city. Ground floor spaces must again with reenacted with minal partitions that are reflected in examples that have achieved the required comfort conditions with minimal energy spent. As Asia modernizes, its diverse and rich identities are increasingly overcome of homogeneity. To go beyond the normal limitations of ethnicity or locale, there must be an effort to identify and debate into the universal and 'shared' principles, a mapping of these ethos and types are necessary and these suggests a certain requirement of setback which defer from that within the urban design guidelines of present times. A higher serendipitious index of a city involved and necessitates a relook towards a richer topical urban experience, must be reenacted and culturally and climatically indigenized. The climatic form thus becomes part of the 'cultural' forms of expression and these have evolved from centuries of refinement and acculturation. Shade and shadow recall the most crucial characteristic of the 
public, the private, and the transitional or semi-public. Architecture under the tropics, climatic forces evolve and affect evolution of spatial expression and strategies of the vernacular which gradually become 'cultural expressions' of its time and potentially part of a nation's search for a cultural identity. The rise of sustainable architecture must not degenerate into homogeneity but must again bring forward the key position of vernacular patterns in evoking strategies in urban form. The paper highlights that how the variations within the generic characteristics of both vernacular urbanism and architecture into the urbanscape, and suggests that a relook into the urban guidelines is critically needed; to reflect their regional and localized forms of green urbanism for the purpose of urban design policy increasingly crucial for developing cities and its regionalised urbanscapes.

\section{Acknowledgements}

The authors would like to acknowledge the Transdisciplinary Research Fund (TRGS16-03-001-0001Characterization of Rules of Malay Architectural Language) from Ministry of Higher Education for the support of this research.

\section{References}

1. Harun NZ, Jaffar N, Kassim SK. Physical attributes significant in preserving the social sustainability of the traditional malay settlement. In: Reframing the vernacular: Politics, semiotics and representation. Springer; 2020.

2. Boeing G. Urban spatial order: Street network orientation, configuration, and entropy. Applied Network Science 2019; 67.

3. Farhana MF, Illyani I, Zalina HN, et al. Analysis of the composition of malay traditional house compound: A case study of Kg Seri Tanjung, Melaka. 2018.

4. Chen F, Romice O. Preserving the cultural identity of Chinese cities in urban design through a typomorphological approach. Urban Design International 2009; 14: 36-54.

5. Sanders P, Baker D. Applying urban morphology theory to design practice. Journal of Urban Design 2016; 21(2): 213-233.

6. Eglash R. African Fractals: Modern computing and indigenous design. New Brunswick: Rutgers University Press; 1999.

7. Hull R. African cities and towns before the European conquest. New York: W. W. Norton; 1976.

8. Schumacher T. Contextualism: Urban ideals and deformations. Casabella 1971; 79-86, 359-360.

9. Batty M, Longley P. Fractal cities: A geometry of form and function. 1st Ed. Academic Press; 1994.

10. Anderson B. Imagined Communities. London: Verso Publishers; 1991.

11. Kiani Z, Amiriparyan P. The structural and spatial analysing of fractal geometry in organizing of Iranian traditional architecture. Procedia - Social and Behavioral Sciences 2016; 216: 766-777.

12. Urban Planning and Architecture Design for Sustainable Development (UPADSD). 14-16 October 2015.

13. Anwar WF. Identification of the morphological characteristic of palembang riverside settlement. Universiti Teknologi Malaysia; 2013.

14. Denpaiboon C. Transformation by modernization of the traditional waterfront settlements in the context of their coexistence with aquatic environment: A case study of raft house and pillar house in Thailand. Kyoto University; 2001.

15. Riparian M, Fitria M. 2015. Community cultures in creating the place-bound identity. Palembang, Procedia - Social and Behavioral Sciences 2015; 184: 394-400. 5th Arte Polis International Conference and Workshop - "Reflections on creativity: Public engagement and the making of place”, Arte-Polis 2014 Aug 5, 8-9; Bandung, Indonesia.

16. Colombijn F. Islamic influences on urban form in Sumatra in the seventeenth to nineteenth centuries CE. Indonesia and the Malay World 2004; 32(93): 249-270.

17. Alexander Christopher. A new theory of urban design. Oxford University Press; 1987.

18. Samsuddin N. The physical design attributes of traditional Malay Kampung in Kampung Tanjung Bunut, Kuala Terengganu. IGCESH2014, Universiti Teknologi Malaysia, Johor Bahru, Malaysia; 2014 Aug 19-21.

19. Kusno. The appearances of memory: Mnemonic practices of architecture and urban form in Indonesia. Duke University Press; 2010 Feb 4.

20. Nor Zalina H, Ismail S. The changing roles of public spaces in Malaysia. International Journal of Social Science and Humanity 2014; 4(5).

21. Evers HD, Korf R. Southeast Asian urbanism: The Meaning and Power of Social Space. 2000.

22. Wiryomartono B. Urbanism, place and culture in the Malay world: The politics of domain from pre-colonial to post-colonial era. City, Culture and Society 2013; 4(4): 217-227.

23. Cakaric J. Water phenomenon: Urban morphology transformation. Facta Universitatis - series Architecture and Civil Engineering 2010; 8(4): 375-388. doi: 10.2298/FUACE1004375C.

24. Stark M. (2015). Southeast Asian urbanism: From early city to Classical state. In: N. Yoffee (Ed.). The Cambridge World History. Cambridge: Cambridge University Press; 2015. p. 74-93.

25. Gospodini A. Urban design, urban space morphology, urbantourism: An emerging new paradigm concerning their relationship. European Planning Studies 2001; 9(7). 
26. Boussaa D. Souk Waqif, a case of urban regeneration and sustainability in Doha's vanishing urban heritage, Qatar. Journal of Urban Regeneration and Renewal 2015 Received (in revised form): 13th August, 2014.

27. Lucia MD, Trunfio M, Go FM. Heritage and urban regeneration: Towards creative tourism. In: Bellini N, Pasquinelli C. (editors). Tourism in the City. Springer, Cham 2017.

28. Koninck RD. Alor Setar, the capital of Kedah: A city to govern agriculture. Archipel 1988; 36(1): 147-164.

29. Rasyid MSA.Understanding the past for a sustainable future: Cultural mapping of Malay heritage. Procedia - Social and Behavioral Sciences 2015; 170: 10-17.

30. Noha N. Planning for urban heritage places: Reconciling conservation, tourism, and sustainable development. Journal of Planning Literature 2003; 17(4).

31. Smith MK. Space, place and placelessness in the culturally regenerated city. In: Richards G (editors). Cultural tourism: Global and local perspectives. Binghampton: The Haworth Press; 2007. p. 91-119.

32. Cushman CL. Study tour fellowship report, architectural layers of a Southeast Asian region: Vietnam and Cambodia Field Seminar. Columbia University; 2017 Jan 27.

33. Ibrahim I, Abdul Latip NS, Jahn Kassim PS, et al.
Historical "Intimacy” in Malay urban core configurations: A comparative analysis. Proceedings of INHERIT conference Sarawak; 2018.

34. Lillevold K, Haarstad H. The deep city: Cultural heritage as a resource for sustainable local transformation. Local Environment 2019; 1-13.

35. Speake J, Fox V. Investigating culturally-led urban regeneration. Teaching Geography 2000; 25(2): 56-60. Published by: Geographical Association.

36. The Star. Arts and culture digital promotion starts with Kuala Kangsar, Website: https://www.thestar.com.my/metro/metro-news/201 8/10/06/arts-and-culture-digital-promotion-starts-wi th-kuala-kangsar/, (Cited Date: 21st March 2018).

37. Khirfan L. Traces on the palimpsest: Heritage and the urban forms of Athens and Alexandria. Cities 2010; (27)5: 315-325.

38. Fang Y, Ceola S, Paik K, et al. Globally universal fractal pattern of human settlements in river networks. Earth's Future 2018; 6: 1134-1145.

39. Das K, Datta S. Man-made environmental degradation at Sunderbans. Reason-A Technical Journal 2014.

40. Yeang K. The tropical Verandah City. Longman Publishers; 1981.

41. Elrahman ASA, Asaad M. Urban design \& urban planning: A critical analysis to the theoretical relationship gap. Ain Shams Engineering Journal 2020. 